\title{
Molecular Survey of Hepatozoon canis in Dogs from Samsun Province of Northern Part of Turkey
}

\author{
Cenk Soner Bölükbaş ${ }^{1}$, Didem Pekmezci², Ali Tümay Gürler ${ }^{1}$, Gökmen Zafer Pekmezci ${ }^{3}$ Murat \\ Güzel$^{2}$, Mustafa Açici' ${ }^{1}$, Şinasi Umur ${ }^{1}$ \\ ${ }^{1}$ Department of Parasitology, Faculty of Veterinary Medicine, University of Ondokuz Mayis, Samsun \\ ${ }^{2}$ Department of Internal Medicine, Faculty of Veterinary Medicine, University of Ondokuz Mayis, Samsun \\ ${ }^{3}$ Preclinical Sciences, Faculty of Veterinary Medicine, University of Ondokuz Mayis, Samsun
}

Geliş Tarihi / Received: 06.10.2016, Kabul Tarihi / Accepted: 15.11.2016

\begin{abstract}
We attempt to address new information of haematozoan infections in dogs from Samsun province of Turkey. The diagnostic techniques using genus specific polymerase chain reaction designed to amplify a fragment of $\sim 666$ bp located in 18S ribosomal RNA (rRNA) gene of Hepatozoon spp. include microscopic investigations. H. canis identities were confirmed by sequencing the $18 \mathrm{~S}$ rRNA gene. Two hundred (170 stray and 30 owned dogs) blood samples from asymptomatic dogs treated for endo and ecto parasites were examined. There were no detected ticks on dogs in the clinical examinations. None of 200 thin blood smears were positive for the presence of Hepatozoon spp. gametocytes. Only one dog sample from 200 with a prevalence of $0.5 \%$ was found to be positive for the presence of Hepatozoon DNA demonstrates a chronic infection. Partial sequences of the 18S rRNA gene shared 99-100\% similarity with the corresponding $H$. canis isolates. Contrary the other molecular surveys on $H$. canis among Turkey, this research revealed a very low prevalence of $H$. canis in dogs from Samsun province of Turkey, and it indicates that ectoparasite control programs have a great impact on decreasing the vector borne parasitic diseases especially in the stray and owned dogs.
\end{abstract}

Key Words: 18S rRNA gene, DNA sequencing, Hepatozoon canis, dogs, Samsun, Turkey

\section{Türkiye'nin Samsun İlindeki Köpeklerde Hepatozoon canis’in Moleküler İncelenmesi}

\begin{abstract}
Özet: Bu araştırmada Samsun'da köpeklerde haematozoan enfeksiyonlar hakkında yeni bilgilerin verilmesi amaçlanmıştır. Bu amaçla mikroskobik inceleme ile birlikte Hepatozoon spp.' nin 666 baz uzunluğundaki 18S ribosomal RNA (rRNA) gene bölgesini amplifiye eden cins spesifik polimeraz zincir reaksiyon metodu kullanıldı. 18S rRNA gene bölgesinin dizi analizi ile H.canis identifiye edildi. Endo ve ektoparazit tedavisi yapılmış asemptomatik köpeklerden 200 (170 sokak ve 30 sahipli) kan örneği topland1. Köpeklerin klinik muayenelerinde keneler saptanmadi. Çalışmada 200 kan frotisinin mikroskobik bakısında Hepatozoon spp. gametositlerine rastlanmadı. Araştırmada \% 0,5 enfeksiyon oranında 200 örnekten sadece 1 köpekte Hepatozoon DNA'sı pozitif bulunması kronik enfeksiyonu işaret etmektedir. Araştırmada pozitif bulunan örneğin 18S rRNA geninin kısmi DNA dizisi dünyadaki diğer $H$. canis izolatları ile \% 99-100 oranında benzerlik gösterdi. Bu çalışmada Türkiye genelindeki H. canis'in moleküler incelemelerinin aksine Samsun yöresindeki köpeklerde çok düşük enfeksiyon oranı ile karşılaşıldı. Bu durum sokak ve sahipli köpeklerde vektör kaynaklı paraziter hastalıkların azaltılması noktasında özellikle ektoparazit kontrol programlarının önemini ortaya koymaktadir.
\end{abstract}

Anahtar Kelimeler: 18S rRNA gen, DNA dizi analizi, Hepatozoon canis, köpek, Samsun, Türkiye

\section{Introduction}

Hepatozoon is a tick borne protozoan parasite, classified in the Phylum Apicomplexa and is closely related to Plasmodium spp. and Piroplasms. Representatives of the genus infecting dogs occur both in the New and the Old World. The two species $H$. canis and $H$. americanum, with distinct clinical, pathological, genetic, antigenic aspects and vectors of transmission especially have importance on dogs. However, the distribution of $H$. americanum is re- stricted to the United States; H. canis is geographically more widespread - including the America, the tropical and temperate zone of Europe, Africa, southwestern Asia, southern and Eastern Europe $[5,7,12]$.

Chronically reports and surveys on hepatozoonozis in Turkey have been started with a first case report in Turkey in 1933 [15], thereafter another case report of this disease has been followed [16]. A parasitological, molecular and serological survey 
of $H$. canis infection in dogs around the Aegean coast of Turkey including Central Aydin, Kusadasi, Selcuk, Central Manisa, Bodrum and Marmaris was presented by Karagenc et al. [10]. Based on molecular investigations of Hepatozoon species in dogs reported the infection source as Diyarbakir an inner province of Turkey [2]. Later, Düzlü et al. [8] reported $H$. canis infection in dogs from Kayseri province by Real Time PCR. Moreover, Aktas et al. [1] also reported another molecular and serological survey of $H$. canis infection in domestic dogs from five coastal provinces (Sakarya, Kocaeli, Mersin, Giresun, and Izmir) and four inland provinces (Elazig, Erzurum, Ankara, and Nevsehir) of Turkey. Finally, molecular detection and characterization of Hepatozoon spp. in dogs reported from different locations throughout Konya and Karaman provinces located in Central Anatolia Region of Turkey [4].

Showing different ecological and climate conditions the Middle Black Sea Region of Turkey has a great importance of the distribution of vector borne parasitic diseases. Therefore, a molecular study was attempted to determine the prevalence of Hepatozoon spp. infection in a coastal province, Samsun, from the Middle Black Sea Region of Turkey by using blood smear, and PCR amplification and DNA sequencing was conducted to identify Hepatozoon species.

\section{Materials and Methods}

\section{Animals}

A total of 200 domestic dog blood samples were collected from Samsun province of Turkey. The field work was undertaken in collaboration with Samsun Metropolitan Municipality's Incapacitated Orphaned Animal Care Center officers, and colleges in the Ondokuz Mayis University Faculty of Veterinary Medicine's Teaching Animal Hospital. Of the total number of 200 dogs with different breeds and sexes, 170 were from municipal shelters, 30 from the Ondokuz Mayis University Faculty of Veterinary Medicine's Teaching Animal Hospital. Because of the shelter management policy all dogs that were enrolled in the study were treated for endo and ecto parasites, same as all owned dogs were also treated for endo and ecto parasites. Based on their detailed clinically examinations dogs were determined as asymptomatic. Venous blood was taken from the cephalic vein, with $2 \mathrm{ml}$ evacuated into a plain additive tube with K3 EDTA ( 7.5 per cent $0.040 \mathrm{ml}$ ) for blood firm sampling and PCR. Sampling procedures was conducted between 2010 and 2013. The protocol for sampling had been reviewed and approved by the Ethical Review Committee of the Ondokuz Mayis University (No: HAYDEK/109). Thin blood smears were taken from the cephalic vein, fixed with ethanol, stained with Giemsa, and screened for Hepatozoon gametocytes.

\section{DNA isolation, amplification and sequencing}

The genomic DNA was extracted from blood samples using a DNeasy Blood and Tissue Kit (Qiagen) according to manufacturer's instruction. Polymerase chain reaction (PCR) targeting the partial 18S rRNA gene sequences of Hepatozoon spp. were performed. PCR was carried out in a final volume of $50 \mu \mathrm{l}$, containing 10-50 ng of extracted DNA, 1X PCR Buffer with KCI (Thermo Scientific), $1.5 \mathrm{mM}$ of $\mathrm{MgCl}_{2}$ (Thermo Scientific), $0.2 \mathrm{mM}$ each dNTPs (Thermo Scientific), 20 pmol of each primer and $2 \mathrm{U}$ of Taq DNA Polymerase (Thermo Scientific). Fragments of $\sim 666 \mathrm{bp}$ of the partial $18 \mathrm{~S}$ rRNA gene were amplified using the primers HepF (5'-ATACATGAGCAAAATCTCAAC-3') and HepR (5'-CTTATTATTCCATGCTGCAG-3') [9]. The PCR was performed in a Thermo PxE 0.2 thermal cycler (Thermo Scientific) and the conditions were as follows: $5 \mathrm{~min}$ at $94^{\circ} \mathrm{C}$, then 30 cycles of $30 \mathrm{~s}$ at $94^{\circ} \mathrm{C}, 30 \mathrm{~s}$ at $55^{\circ} \mathrm{C}$ and $1 \mathrm{~min}$ at $72^{\circ} \mathrm{C}$ followed by a final elongation of $5 \mathrm{~min}$ at $72^{\circ} \mathrm{C}$. PCR products were electrophoresed in $1.5 \%$ agarose gel (Prona) in a TBE buffer ( 89 mMTris, $89 \mathrm{mM}$ boric acid, 2 mM EDTA, pH 8.3) (Thermo Scientific), stained with ethidium bromide (Sigma) and visualized by UV transillumination (DNR, Bio-imaging system). The size of the amplified fragments was estimated by comparisons with the 1000 bp DNA Ladder (Thermo Scientific).

Hepatozoon canis identities were confirmed by sequencing the $18 \mathrm{~S}$ rRNA gene. The $18 \mathrm{~S}$ rRNA gene amplification product was sent to sequencing company (Macrogen, Korea) for purification and sequencing in both directions using same primers. Sequencing was carried out directly on purified fragments with ABI PRISIM 310 genetic analyzer 
(Applied Biosystems, Foster City, CA, USA), using the ABI PRISIM ${ }^{\circledR}$ BigDye terminator cycle sequencing ready reaction kit. Sequence quality was assessed using Vector NTI Advance 11.5 (Invitrogen).

\section{Phylogenetic analysis}

The obtained sequences were verified by forward and reverse comparisons, assembled and edited with using Contig Express in Vector NTI Advance 11.5 (Invitrogen). The obtained consensus sequences were compared with previously published data for identification by using the Basic Local Alignment Search Tool (BLAST) via GenBank database [3]. Sequences were aligned with previously characterized sequences of other known $H$. canis using ClustalW in Mega 5.0 (http://www.megasoftware. net/) multiple sequence alignments [14] and adjusted manually. Genetic distances were calculated using the Kimura two-parameter model with pairwise deletion in Mega 5.0 [13]. The nucleotide sequence was deposited in GenBank database under the accession numbers: KX588232.

\section{Results}

In the present study, information on ecto parasiticide treatment was available for all dogs. Therefore, there were no detected ticks on dogs in the clinical examinations. None of 200 thin blood smears were positive for the presence of Hepatozoon spp. gametocytes. In contrast, results out of 200 samples, only $1(0.5 \%)$ were found positive in terms of Hepatozoon spp. by PCR in the stray dog. The only PCR-positive sample was confirmed by $18 \mathrm{~S}$ rRNA gene sequence comparisons in Genbank. The percent identities among $H$. canis isolates from Turkey (Samsun, KX588232) showed 99-100 \% identity with various geographical isolates of $\mathrm{H}$. canis from the Iran (KT736298), Hungary (KJ572976), Italy (GU371447; GU371448; GU371449; GU371450; KP644235), Malaysia (KT267961), Croatia (FJ497019; FJ497022; HM212626), Brazil (AY461375) and Spain (AY150067) from GenBank. Moreover, in Turkey, pairwise comparison between the 18S rRNA gene sequences of the $H$. canis isolates from Samsun (KX588232) and other $H$. canis isolates from different regions (strain H130, KF034776; Konya B172, KF439867; Aydın, DQ060328; Kusadasi, DQ060324; Selcuk, DQ060329; Bodrum, DQ060327; Marmaris, DQ060326; TrKysHcan1, KJ513198; isolate DD11, JQ867390; Konya B167, KF439866; Manisa, DQ060325) showed differences ranging from 0.0 to $0.9 \%$ (Table 1 ).

Table 1. Pairwise comparison of nucleotide sequence differences (in percent) in the $18 \mathrm{~S}$ rRA among $H$. canis isolates in Turkey.

\begin{tabular}{|c|c|c|c|c|c|c|c|c|c|c|c|c|}
\hline & 1 & 2 & 3 & 4 & 5 & 6 & 7 & 8 & 9 & 10 & 11 & 2 \\
\hline 1. Samsun, KX588232 & - & & & & & & & & & & & \\
\hline 2. strain H130, KF034776 & 0.000 & - & & & & & & & & & & \\
\hline 3. Konya B172, KF439867 & 0.002 & 0.002 & - & & & & & & & & & \\
\hline 4. Aydin, DQ060328 & 0.005 & 0.005 & 0.007 & - & & & & & & & & \\
\hline 5. Kusadasi, DQ060324 & 0.005 & 0.005 & 0.007 & 0.000 & - & & & & & & & \\
\hline 6. Selcuk, DQ060329 & 0.007 & 0.007 & 0.009 & 0.002 & 0.002 & - & & & & & & \\
\hline 7. Bodrum, DQ060327 & 0.007 & 0.007 & 0.009 & 0.002 & 0.002 & 0.000 & - & & & & & \\
\hline 8. Marmaris, DQ060326 & 0.007 & 0.007 & 0.009 & 0.002 & 0.002 & 0.000 & 0.000 & - & & & & \\
\hline 9. TrKysHcan1, KJ513198 & 0.007 & 0.007 & 0.009 & 0.002 & 0.002 & 0.000 & 0.000 & 0.000 & - & & & \\
\hline 10. isolate DD11, JQ867390 & 0.007 & 0.007 & 0.009 & 0.002 & 0.002 & 0.000 & 0.000 & 0.000 & 0.000 & - & & \\
\hline 11. Konya B167, KF439866 & 0.007 & 0.007 & 0.009 & 0.002 & 0.002 & 0.000 & 0.000 & 0.000 & 0.000 & 0.000 & - & \\
\hline 12. Manisa, DQ060325 & 0.009 & 0.009 & 0.011 & 0.005 & 0.005 & 0.007 & 0.007 & 0.007 & 0.007 & 0.007 & 0.007 & - \\
\hline
\end{tabular}




\section{Discussion}

Hepatozoonosis as one of the other tick-borne diseases plays a major hazard to domestic and wild canids globally. Therefore, epidemiological studies are essential to describe the trends of infection with a particular pathogen and its vectors locally and regionally. Knowledge on vector-borne infections at the local level allows veterinary practitioners to recognize the pathogens that can affect their patients facilitating a prompt diagnosis and treatment [6]. To date no study about canine hepatozoonosis from Samsun province of Turkey has been reported. Although PCR is considered the most sensitive detection method for canine hepatozoonosis, microscopic examination of blood smears is a simple technique frequently used for the diagnosis of this infection. This technique may be used also as an epidemiological tool for studies in areas were canine hepatozoonosis is endemic or where it is suspected [11]. However, negative results may lead misdiagnosis of the disease especially in tick free patients.

Previous studies even molecularly presented in different part of Turkey represented higher infection rates $[1,2,4,8,10,16]$ contrarily to our results. One of the explanations of this very low infection rate of our result may be depended to the successful ecto parasite treatment of the sampled dogs. While, all shelter samples same as all owned dogs were also treated for endo and ecto parasites. The only positive result of the study also demonstrates the chronic infection in the dogs, which only could be detected by PCR. Same as Otranto et al. [11], this study suggests that when no information is available on the date of potential infective tick exposure, PCR on either blood or buffy coat should be preferred to cytology for the diagnosis of $H$. canis infection. This detection of the chronic infection even in one sample shows the distribution of hepatozoonozis in Samsun province, and precautions should be taken for disease protection.

Therefore, we believe that this molecular survey has an importance for clarifying the canine hepatozoonosis, and guide the practitioners for continuing ecto parasite treatment who may suffer patients have with high fever and potential infective tick exposure in the northern part of Turkey.

\section{Acknowledgement}

This study was supported by The Scientific Research Council of Ondokuz Mayis University in Samsun, Turkey (Project number PYO.VET.1901.13.003).

\section{References}

1. Aktas M, Ozubek S, Altay K, Balkaya I, Utuk AE, Kırbas A, Simsek S, Dumanlı N, (2015). A molecular and parasitological survey of Hepatozoon canis in domestic dogs in Turkey. Vet Parasitol. 209(3), 264-267.

2. Aktas M, Ozubek S, Ipek DNS, (2013). Molecular investigations of Hepatozoon species in dogs and developmental stages of Rhipicephalus sanguineus. Parasitol Res. 112(6), 2381-2385.

3 Altschul SF, Gish W, Miller W, Myers EW, Lipman DJ, (1990). Basic local alignment search tool. J Mol Biol. 215(3), 403-410.

4. Aydin MF, Sevinc F, Sevinc M, (2015). Molecular detection and characterization of Hepatozoon spp. in dogs from the Central part of Turkey. Ticks and Tick-borne Diseases. 6(3), 388-392.

5. Baneth G, (2011). Perspectives on canine and feline hepatozoonosis. Vet Parasitol. 181(1), 3-11.

6. Baneth G, Bourdeau P, Bourdoiseau G, Bowman D, Breitschwerdt E, Capelli G, Cardoso L, Dantas-Torres F, Day M, Dedet JP, Dobler G, Ferrer L, Irwin P, Kempf V, Kohn B, Lappin M, Little S, Maggi R, Miro G, Naucke T, Oliva G, Otranto D, Penzhorn B, Pfeffer M, Roura X, Sainz A, Shaw S, Shin S, Solano-Gallego L, Straubinger R, Traub R, Trees A, Truyen U, Demonceau T, Fitzgerald R, Gatti D, Hostetler J, Kilmer B, Krieger K, Mencke N, Mendao C, Mottier L, Pachnicke S, Rees B, Siebert S, Stanneck D, Tarancon Mingote M, von Simson C, Weston S, (2012). Vector-Borne Diseasesconstant challenge for practicing veterinarians: recommendations from the CVBD World Forum. Parasites \& Vectors, 5, 55-58.

7. Baneth G, Vincent-Johnson N, (2005). Hepatozoonosis. Shaw SE, Day MJ. eds. Arthropod-borne Infectious Diseases of the Dog and Cat. Manson Publishing, London. p. 78-89.

8. Düzlü Ö, İnci A, Yıldırım A, Önder Z, Çiloğlu A, (2014). Köpeklerde kene kaynakl bazl protozoon ve rickettsial enfeksiyonlarin real time PCR ile araştırlması ve saptanan izolatların moleküler karakterizasyonlarl. Ankara Univ Vet Fak Derg. 61, 275-282.

9. Inokuma H, Okuda M, Ohno K, Shimoda K, Onishi T, (2002). Analysis of the 18S rRNA gene sequence of a Hepatozoon detected in two Japanese dogs. Vet Parasitol, 106, 265-271.

10. Karagenc TI, Pasa S, Kirli G, Hosgor M, Bilgic HB, Ozon YH, Atasoy A, Eren H, (2006). A parasitological, molecular and serological survey of Hepatozoon canis infection in dogs around the Aegean coast of Turkey. Vet Parasitol. 135(2), 113-119.

11. Otranto D, Dantas-Torres F, Weigl S, Latrofa MS, Stanneck D, Decaprariis D, Baneth G, (2011). Diagnosis of Hepatozoon canis in young dogs by cytology and PCR. Parasites \& Vectors, 4(1), 55.

12. Smith TG, (1996). The genus Hepatozoon (Apicomplexa: Adeleina). J Parasitol. 82, 565-585.

13. Tamura K, Peterson D, Peterson N, Stecher G, Nei M, Kumar S, (2011). MEGA5: molecular evolutionary genetics analysis using maximum likelihood, evolutionary distance, and maximum parsimony methods. Mol Biol Evol. 28(10), 2731-2739.

14. Thompson JD, Higgins DG, Gibson TJ, (1994). CLUSTAL W: improving the sensitivity of progressive multiple sequence alignment through sequence weighting, position-specific gap penalties and weight matrix choice. Nucleic Acids Res. 22(22), 4673-4680.

15. Tuzdil AN, (1933). Bizde ilk defa görülen bir Hepatozoon canis vakası. Türk Bay Cem Mec. 13, 35.

16. Voyvoda H, Pasa S, Uner A, (2004). Clinical Hepatozoon canis infection in a dog in Turkey. J Small Anim Pract. 45(12), 613-617. 